\title{
SISTEM PAKAR DENGAN METODE DEMPSTER-SHAFER UNTUK DIAGNOSA PENYAKIT AYAM BROILER
}

\author{
UL Khairat', Akhmad Qashlim² \\ ${ }^{1,2}$ Program Studi Sistem Informasi, Universitas Al Asyariah Mandar, Polewali Mandar, Indonesia \\ uㅣkhairat@mail.unasman.ac.id, ㄹa ashlim@mail.unasman.ac.id
}

\begin{abstract}
ABSTRAK
Produksi peternakan ayam broiler berkembang semakin cepat seiring dengan semakin meningkatnya permintaan pasar terhadap ayam pedaging yang mengandung protein hewani yang banyak dikonsumsi oleh masyarakat. Ayam broiler memiliki pertumbuhan daging yang cepat dalam waktu yang relative singkat. Salah satu faktor yang menjadi penghambat dalam budidaya ayam broiler ini adalah ayam broiler ini sangat mudah terserang penyakit dan menular keayam lainnya secara cepat pula jika penanganan lambat. Penelitian ini akan merancang system pakar untuk mendiagnosa lebi awal penyakit ayam broiler menggunakan Metode Dempster Shafer untuk membangun mesin inferensi. Sistem dibangun berbasis web menggunakan baasa pemrograman PHP dan MySQL Data base. Output diagnosa yang di hasilkan merupakan jenis penyakit, penyebab, dan cara mengatasi penyakit serta nilai evidence (bukti) keyakinan yang diderita oleh ayam. Percobaan dilakukan pada 15 ekor ayam dan 10 jenis penyakit Asil penelitian menunjukkan nilai persentase Chronic Respiratory Disearce (CRD) dengan nilai keyakinan $82.46 \%$.
\end{abstract}

Kata Kunci-Sistem Pakar, Metode Dempster Shafer, Ayam Broiler, Diagnosa Penyakit

\begin{abstract}
The production of broiler chicken farms is growing faster in line with the increasing market demand for broilers containing animal protein which is widely consumed by the public. Broiler chickens have fast meat growth in a relatively short time. One of the factors that is an obstacle in the cultivation of broiler chickens is that broilers are very susceptible to disease and infectious diseases of other types of chickens quickly if handling is slow. This study will design an expert system to diagnose earlier diseases of broiler chickens using the Dempster Shafer Method to build an inference engine. The system is built based on web using PHP programming language and MySQL data base. The output of the resulting diagnosis is the type of disease, the cause, and how to deal with the disease as well as the value of evidence (evidence) of belief suffered by chickens. The experiment was carried out on 15 chickens and 10 types of Asyl diseases. The study showed a percentage value of Chronic Respiratory Disearce (CRD) with a confidence value of $82.46 \%$.
\end{abstract}

Keywords - Expert System, Dempster Shafer Method, Broiler Chickens, Disease Diagnosis 
JurnalllmiahIlmuKomputer Vol. 5, No. 1, April 2019

Fakultas Ilmu Komputer

Universitas AL Asyariah Mandar

\section{PENDAHULUAN}

Kemampuan sistem pakar yang menggunakan pengetahuan, fakta, dan teknik penalaran dalam memecahkan masalah menjadi salah satu alternatif yang banyak digunakan oleh orang-orang dalam menemukan solusi. Sistem pakar yang mampu meniru kerja dari para ahli [1]. Sistem pakar yang dirancang dengan tingkat user frendly yang tinggi dapat digunakan oleh orang awam untuk menemukan solusi dari masalah yang rumit, kondisi ini menjadikan sistem pakar mulai digunakan oleh berbagai bidang disiplin ilmu, dan berkembang dengan cepat [2].

Pada sebuah kasus peternakan ayam broiler yang mana tingkat produksinya memiliki perkembangan yang semakin cepat seiring dengan semakin meningkatnya permintaan pasar terhadap ayam pedaging ini [3]. Ayam broiler merupakan salah satusumber protein hewani yang banyak dikonsumsi oleh masyarakat. Ayam broiler memiliki pertumbuhan daging yang cepat dalam waktu yang relatif singkat [2]. Namun belakangan ditemukan salah satu faktor yang menjadi penghambat dalam budidaya ayam broiler ini adalah lemahnya daya tahan tubuh dan mudah diserang penyakit [4]. Ada berbagai macam penyakit yang dapat menyerang ayam broiler, diantaranya adalah tetelo, ngorok, berakkapur, gumboro, colibacillosis, berakdarah, snot, flu burung, dan necrotic enteritis [2]. Kurangnya informasi yang dimiliki oleh para peternak tentang gejala dan diagnosa penyakit ayam broiler menjadikan penanganan penyakit menjadi lambat dan berakibat kematian pada ayam. Jika persentase kematian ayam cukup tinggi sebelum masa panen, maka para peternak akan mengalami kerugian [5].

Kondisi tersebut dapat diantisipasi dengan memanfaatkan teknologi informasi berbasis aplikasi. Sebuah sistem pakar yang dirancang dengan pengetahuan mengenai penanganan ayam broiler dapat menjadi solusi untuk masalah tersebut [6].

Penelitian ini akan merancang sistem pakar untuk mensiagnosa lebih awal tentang penyakit ayam broiler. Untuk mengoptimalikan kerja dari sistem pakar ini akan maka akan digunakan metode Dempster-Shafer [7].

Metode Dempster-Shafer mampu menunjukkan suatu cara untuk memberikan bobot kenyakinan sesuai fakta yang dikumpulkan dan menjadin basisa pengetahuan dari sistem pakar yang dibangun [8].

Sistem pakar dengan metode Dempster-Shafer diharapkan dapat menjadi solusi untuk menemukan penanganan pertam dari masalah penyakit pada ayam broiler. Keterlibatan pakar dalam perancangan sistem akan menjadi penentu dari tingkat keyakinan dan akurasi sistem pakar yang dirancang.

\section{TINJAUAN PUSTAKA}

\subsection{Konsep Sistem Pakar}

Sebagian besar para ahli, sistem pakar ini juga akan membantu aktivitasnya sebagai asisten yang sangat berpengalaman [1]. Konsep dasar sistem pakar mengandung keahlian, ahli/pakar, pengalihan keahlian, mengambil keputusan, aturan, kemampuan menjelaskan [9]. Konsep dasar dijelaskan sebagai berikut:
(P) ISSN 2442-451X

(O) ISSN 2503-3832

1. Keahlian

Keahlian adalah suatu kelebihan penguasaan pengetahuan di bidang tertentu yang diperoleh dari pelatihan, membaca atau dari pengalaman.

Bentuk pengetahuan yang termasuk keahlian:

1. Fakta-fakta pada lingkup permasalahan tertentu.

2. Teori-teori pada lingkup permasalahan tertentu.

3. Aturan-aturan berkenaan dengan lingkup permasalahan tertentu.

4. Meta -knowledge (pengetahuan tentang pengetahuan)

2. Ahli / Pakar

Seorang ahli adalah se- seorang yang mampu menjelaskan suatu tanggapan, mempelajari hal-hal baru seputar topik permasalahan, menyusun kembali pengetahuan jika dipandang perlu, memecahkan masalah dengan cepat dan tepat.

3. Pengalihan Keahlian

Tujuan dari sistem pakar adalah untuk mentransfer keahlian dari seorang pakar kedalam komputer kemudian kemasyarakat. Proses ini meliputi 4 kegiatan, yaitu perolehan pengetahuan (dari para ahli atau sumber-sumber lainnya), representasi pengetahuan kekomputer, kesimpulan dari pengetahuan dan pengalihan pengetahuan kepengguna.

4. Mengambil Keputusan

Hal yang unik dari sistem pakar adalah kemampuan untuk menjelaskan dimana keahlian tersimpan dalam basis pengetahuan. Kemampuan komputer untuk mengambil kesimpulan dilakukan oleh komponen yang dikenal dengan mesin inferensi yaitu meliputi prosedur tentang pemecahan masalah.

5. Aturan (Rule)

Sistem pakar yang dibuat merupakan sistem yang berdasarkan pada aturan - aturan dimana program disimpan dalam bentuk aturan-aturan sebagai prosedur pemecahan masalah. Aturan tersebut biasanya berbentuk $I F-T H E N$.

6. Kemampuan Menjelaskan

Keunikan lain dari sistem pakar adalah kemampuan dalam menjelaskan atau memberi saran/rekomendasi serta juga menjelaskan mengapa beberapa tindakan/saran tidak direkomendasikan.

Gambar 2.1 menunjukkan konsep dasar suatu sistem pakar knowledge-base. Pengguna menyampaikan fakta atau informasi untuk siste mpakar dan kemudian menerima saran dari pakar atau jawaban ahlinya. Bagian dalam sistem pakar terdiri dari dua komponen utama, yaitu knowledge base yang berisi knowledge dan mesininferensi yang menggambarkan kesimpulan. Kesimpulan tersebu tmerupakan respons dari sistem pakar atas permintaan pengguna. 
JurnalIlmiahIlmuKomputer Vol. 5, No. 1, April 2019

Fakultas Ilmu Komputer

Universitas AL Asyariah Mandar

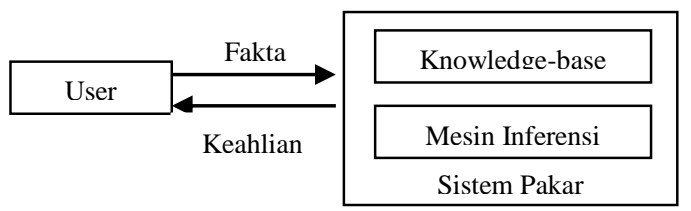

Gambar 2.1. Konsep Dasar Fungsi Sistem Pakar

Sistem pakar disusun oleh dua bagianutama, yaitu lingkungan pengembangan (development environment) dan lingkungan konsultasi (consultation environment). Lingkungan pengembangan sistem pakar digunakan untuk memasukkan pengetahuan sistem pakar kedalam lingkungan sistem pakar, sedangkan lingkungan konsultasi digunakan oleh pengguna yang bukan pakar guna memperoleh pengetahuan pakar [10]

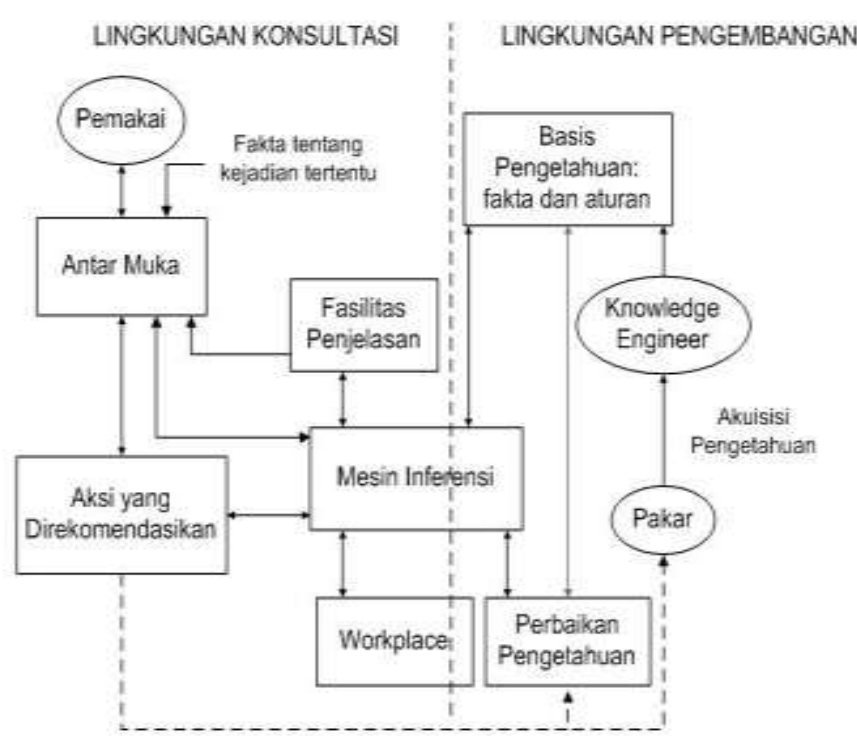

Gambar 2.2. StrukturSistemPakar [10]

\subsection{Metode Dempster-Shafer}

Metode Dempster-Shafer pertama kali diperkenalkan oleh Dempster, yang melakukan percobaan model ketidak pastian dengan range probabilities dari pada sebagai probabilitas tunggal. Kemudian pada tahun 1976 Shafer mempubli.kasi kanteori Dempster itu pada sebuah buku yang berjudu 1Mathematical Theory Of Evident. Dempster-Shafer Theory of Evidence, menunjukkan suatu cara untuk memberikan bobot kenyakinan sesuaifakta yang dikumpulkan [11]. Pada teori ini dapat membedakan ketidak pastian dan ketidaktahuan. TeoriDempster-Shafer adalah representasi, kombinasi dan propogasi ketidak pastian [12], dimana teori ini memiliki bebera pakar akteristik yang secara instutitif sesuai dengan cara berfikir seorang pakar, namun dasar matematika yang kuat [13].

Secara umum teori Dempster-Shafer ditulis dalam suatu interval : [Belief,Plausibility]

1. Belief $(\mathrm{Bel})$ adalah ukuran kekuatan evidence dalam mendukung suatu himpunan proposisi. Jika bernilai 0 maka mengindikasikan bahwa tidak ada evidence, dan jika bernilai 1 menunjukan adanya kepastian. Dimana nilai bel yaitu (0-0.9).

2. Plausibility (Pl) dinotasikan sebagai : $\mathrm{Pl}(\mathrm{s})=1-\mathrm{Bel}(-$ s) Plausibility juga bernilai 0 sampai 1. Jika yakinakan $\mathrm{s}$, maka dapat dikatakan bahwa $\operatorname{Bel}(-\mathrm{s})=1$, dan $\mathrm{Pl}(-\mathrm{s})=0$. Berikut fungsi kombinasi metode Dempster-Shafer :

$$
\mathrm{M}_{3}(\mathrm{z})=\frac{\sum x \cap y=z m_{1}(X) \cdot m_{2}(Y)}{1-\sum x \cap y=\emptyset m_{1}(X) \cdot m_{2}(Y)}
$$

Dimana :

$\mathrm{M} 3(\mathrm{Z})=$ mass function darievidence $(\mathrm{Z})$

$\mathrm{m} 1(\mathrm{X})=$ mass function darievidence $(\mathrm{X})$

$\mathrm{m} 2(\mathrm{Y})=$ mass function darievidence $(\mathrm{Y})$

$\mathrm{Zm} 1(\mathrm{X}) \cdot \mathrm{m} 2(\mathrm{Y})=$ ada hasil irisandari $\mathrm{m} 1$ dan $\mathrm{m} 2$

$\emptyset \mathrm{Zm} 1(\mathrm{X}) \cdot \mathrm{m} 2(\mathrm{Y})=$ tidak ada hasil irisan (irisankosong $(\varnothing)$ )

\subsection{Penyakit Ayam Broiler}

Berikut ini adalah beberapa penyakit pada pada ayam broiler diantaranya adalah sebagai berikut [14]:

1. Penyakit Flu Burung (Avian Influenza).

Flu burung adalah penyakit yang disebabkan oleh virus influenza yang me-nyerang burung/unggas/ayam. Menurut dalam salah satu tipe yang perlu diwaspadai adalah yang disebab-kan oleh virus influenza dengan kode genetik H5N1 yang selain dapat menular dari burung ke burung ternyata dapat pula menular dari bu-rung ke manusia [15].

\section{Penyakit Chronic Respiratory Disearce (CRD)}

Penyakit ini menyerang ayam broiler pada masa pertumbuhanya yaitu antara umur 3-5 minggu. Penyakit ini menyerang saluran pernafasan sehingga dikenal pula dengan nama MG (Mycoplasma Gallisepcticum) atau penyakit saluran pernafasan atau disebut juga PPLO (Pleuropneminia Like Organism). Gejala yang ditimbulkan antara lain bersin-bersin, batuk, ngorok, mata bengkak, pincang, lumpuh

\section{Penyakit Coryza}

Serangan coryza atau pilek ayam bi-asanya diikuti oleh penyakit-penyakit lainnya, antara lain fowl pox, CRD, dan kekurangan vita-min A sehingga sulit dibedakan secara kasat mata antara ayam yang yang terserang CRD atau coryza karena keduanya sering menyerang pada waktu bersamaan

\section{Penyakit Tatelo (Newcastle Disease)}

Penyebaran penyakit ini dapat melalui peralatan peternakan yang baru masuk ke kan-dang yang tidak dicuci terlebih dahulu, selain itu dapat juga disebarkan melalui burung-burung liar yang ada disekitar kandang. Satu-satunya cara untuk pencegahanya adalah dengan vaksinasi. Hanya saja vaksinasi harus dilakukan dengan cara yang benar, dalam vaksinasi harus diperhatikan jenis vaksin dan batas kadaluarsanya. 


\section{Penyakit Gumboro (Gumboro Disease)}

Penyakit ini disebabkan oleh virus yang belum diketahui secara spesifik seluk-beluknya. Penyakit gumboro umumnya menyerang ayam pada masa pertumbuhan. Virus gumboro sulit dideteksi sehingga mampu hidup di luar tubuh ayam selama berbulan-bulan. Kandang yang kotor serta tempat pakan dan peralatan yang tidak bersih menjadi sumber utama penyebaran penyakit ini.

\section{Penyakit Berak Darah (Coccidosis)}

Ayam yang terserang penyakit ini akan menunjukan gejala cukup jelas. Dalam kasus yang sudah parah pada lantai (litter) akan ditemukan bercak-bercak berwarna merah pa-da kotoran ayam karena usus rusak.

\section{METODE PENELITIAN}

\subsection{Pengumpulan Data}

Pengumpulan data dilakukan dengan observasi langsung pada lokasi ternak ayam broiler untuk meliat langsung kondisi ternak dan kandang, ini adala upaya untuk mengumpulkan informasi dan fakta-fakta lingkup permasalaan serta membangun basis pengetauan yang akan digunakan pada system. Kami melakukan simulasi pada 15 ekor ayam untuk mengtaui tingkat konsistensi asil diagnosa dan untuk menguji akurasi pada asil diagnose system.

\subsection{Analisis Data}

a. Data asil observasi yang tela dikumpulkan akan dikoordinasikan dan dikonsultasikan dengan pakar atau ali yang akan terlibat dalam perancangan system.

b. Data dan informasi yang bersumber dari lapangan akan dikuatkan dengan pengetauan pakar. Kemudian digunakan untuk membuat basis pengetauan

c. Setiap komponen pada basis pengetauan akan dibuat kode unik untuk memudakan pengambilan keputusan dan diberi bobot

d. Kode tersebut akan dikenali ole mesin inferensi yang kemudian digunakan untuk pemecaan masala

Adapun table penyakit yang tela dibuat kedalam basis pengetauan dibangun sebagai berikut:

Tabel 3.1. Tabel Penyakit

\begin{tabular}{|c|c|c|}
\hline kd_penyakit & nama_penyakit & Solusi \\
\hline P1 & $\begin{array}{l}\text { Flu Burung } \\
\text { (Avian } \\
\text { Influensa) }\end{array}$ & $\begin{array}{l}\text { Melakukan } \\
\text { kandang dan pesinfeksi } \\
\text { kandang, melarang masuk } \\
\text { orang yang } \\
\text { berkepentingaan, } \\
\text { meminimalkan masuknya } \\
\text { burung / unggas liar, } \\
\text { melakukan vaksinasi yang } \\
\text { mengandung strain virus yang } \\
\text { homolog (sama). } \\
\text { memusnakan semua ayam } \\
\text { yang mati atau yang } \\
\text { terinfeksi. Untuk Pengobatan } \\
\text { belum ada obat yang efektif } \\
\text { untuk menangani penyakit ini. }\end{array}$ \\
\hline $\mathrm{P} 2$ & $\begin{array}{c}\text { Chronic } \\
\text { Respiratory } \\
\text { Disease (CRD) }\end{array}$ & $\begin{array}{l}\text { Melakukan sanitasi kandang } \\
\text { dan disemprot dengan } \\
\text { Antisep, Formades atau } \\
\text { Sporades. Membatasi tamu } \\
\text { dan hewan/unggas lain masuk } \\
\text { ke lingkungan kandang, } \\
\text { kepadatan yang baik, } \\
\text { Ventilasi kandang yang } \\
\text { cukup, peralatan kandang } \\
\text { dicuci sampai bersih } \\
\text { kemudian direndam minimal } \\
30 \text { menit dalam Medisep } \\
15 \text { ml/10 liter air dilakukan } 4 \\
\text { hari sekali. Untuk pengobatan } \\
\text { Tyfural, Medoxy, Doxyvet, } \\
\text { Doctril atau Neo Medetril. } \\
\text { pilih salah satu dan berikan } \\
\text { sesuai aturan pakai. }\end{array}$ \\
\hline P3 & $\begin{array}{c}\text { Infectious } \\
\text { Coryza (Snot, } \\
\text { Pilek) }\end{array}$ & 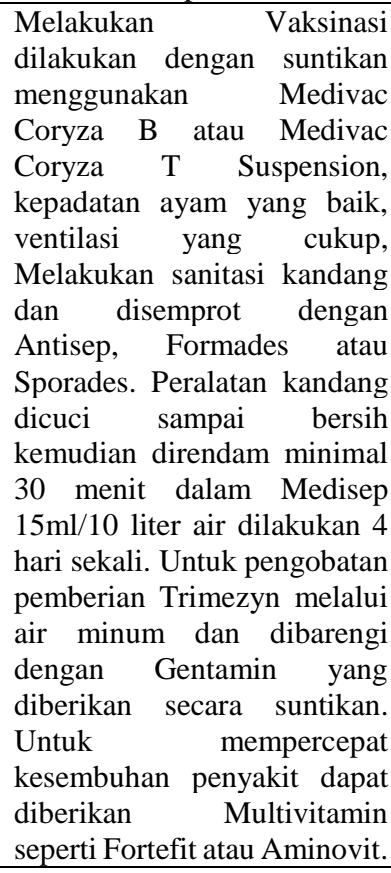 \\
\hline
\end{tabular}




\begin{tabular}{|c|c|c|c|c|c|}
\hline kd_penyakit & nama_penyakit & Solusi & kd_penyakit & nama_penyakit & Solusi \\
\hline \multirow{3}{*}{$\mathrm{P} 4$} & \multirow{3}{*}{$\begin{array}{c}\text { Tatelo } \\
\text { (Newcastle } \\
\text { Disease) }\end{array}$} & \multirow{3}{*}{$\begin{array}{l}\text { Melakukan Vaksinasi ND dan } \\
\text { pemberian Vita Stress selama } \\
3 \text { hari sebelum dan sesudah } \\
\text { vaksinasi. Melakukan sanitasi } \\
\text { kandang dan disemprot } \\
\text { dengan Antisep, Formades } \\
\text { atau Sporades. Membatasi } \\
\text { tamu dan hewan lain masuk } \\
\text { kelingkungan kandang. } \\
\text { Tempat minum dicuci } 2 \text { hari } \\
\text { sekali dan } 4 \text { hari sekali, } \\
\text { direndam dalam Medisep } \\
\text { 15ml tiap 10 Liter air minimal } \\
30 \text { menit. Kepadatan ayam } \\
\text { yang baik dan ventilasi yang } \\
\text { cukup. Untuk Pengobatan } \\
\text { Belum ada obat yang dapat } \\
\text { menyembuhkan penyakit ND. } \\
\text { Untuk mengurangi kematian } \\
\text { lakukan revaksinasi } \\
\text { (vaksinasi Darurat) dengan } \\
\text { Medivac ND Clone } 45 \text { pada } \\
\text { ayam yang kondisinya masih } \\
\text { terlihat sehat. untuk } \\
\text { mencegah infeksi sekunder } \\
\text { memberikan obat ampicol, } \\
\text { Koleriding, Neo Medetril, } \\
\text { Doctril atau Coliquin (pilih } \\
\text { salah satu dan berikan sesuai } \\
\text { aturan pakai). kemudian } \\
\text { berikan Vitamin seperti } \\
\text { Fortevit, Vita Stress dalam air } \\
\text { minum selama } 3 \text { hari berturut- } \\
\text { turut. }\end{array}$} & & & $\begin{array}{l}\text { minum. Untuk mencegah } \\
\text { infeksi sekunder oleh bakteri } \\
\text { dengan memberikan } \\
\text { antibiotika yang tidak } \\
\text { mempunyai efek samping ke } \\
\text { ginjal, misalnya Ampicol atau } \\
\text { Koleridin. }\end{array}$ \\
\hline & & & P6 & $\begin{array}{l}\text { Berak Darah } \\
\text { (Koksidiosis) }\end{array}$ & $\begin{array}{l}\text { Melakukan sanitasi kandang } \\
\text { dan disemprot dengan } \\
\text { Antisep, Formades atau } \\
\text { Sporades. Membatasi tamu } \\
\text { dan hewan lain masuk } \\
\text { kelingkungan kandang. } \\
\text { Peralatan peternakan dicuci } \\
\text { sampai bersih dan rendam } \\
\text { minimal } 30 \text { menit dala } \\
\text { Medisep 15ml tiap } 10 \text { Liter air } \\
\text { dilakukan } 4 \text { hari sekali. } \\
\text { Kepadatan ayam yang baik } \\
\text { dan ventilasi yang cukup. } \\
\text { Untuk pengobatan pemberian } \\
\text { obat Antikoksi, Coxy, } \\
\text { Sulfamix, Therapy, Duoko, } \\
\text { atau Koksides (Pilih salah } \\
\text { satu dan berikan sesuai aturan } \\
\text { pakai). dan Pemberian Vita } \\
\text { stress 4-5 hari setelah } \\
\text { pemberian obat selesai } \\
\text { dilakukan. }\end{array}$ \\
\hline & & & & & $\begin{array}{ll}\text { Melakukan } & \text { pengecekan } \\
\text { kualitas air minum peternakan } \\
\text { terhadap adanya bakteri } \\
\text { Coliform dan } & \text { E.coli., } \\
\text { pemberian Antisep } & 3 \mathrm{ml} \text { tiap }\end{array}$ \\
\hline \multirow[t]{2}{*}{ P5 } & \multirow[t]{2}{*}{$\begin{array}{c}\text { Gumboro } \\
\text { (Gumboro } \\
\text { Disease) }\end{array}$} & \multirow{2}{*}{$\begin{array}{l}\text { Melakukan vaksinasi } \\
\text { Medivac Gumboro Emulsion, } \\
\text { Melakukan sanitasi kandang } \\
\text { dan disemprot dengan } \\
\text { Antisep, Formades atau } \\
\text { Sporades. Membatasi tamu } \\
\text { dan hewan lain masuk } \\
\text { kelingkungan kandang. } \\
\text { Kepadatan Ayam yang baik, } \\
\text { Peralatan peternakan dicuci } \\
\text { sampai bersih dan rendam } \\
\text { minimal } 30 \text { menit dala } \\
\text { Medisep } 15 \text { ml tiap } 10 \text { Liter air } \\
\text { dilakukan } 4 \text { hari sekali. Untuk } \\
\text { pengobatan belum ada obat } \\
\text { yang dapat menyembuhkan } \\
\text { penyakit gumboro. Tindakan } \\
\text { yang dilakukan adalah } \\
\text { mengusahakan supaya } \\
\text { kondisi badan ayam cepat } \\
\text { membaik dengan } \\
\text { memberikan obat Vita Stress } \\
\text { untuk mengatasi dehidrasi } \\
\text { dan meningkatkan nafsu } \\
\text { makan ayam. Pemberian air } \\
\text { gula (gula merah) sebagai } \\
\text { sumber energi dengan takaran } \\
\text { 20-50 Gram tiap } 1 \text { Liter air }\end{array}$} & $\mathrm{P} 7$ & Colibacillosis & $\begin{array}{l}\text { 2liter air minum, Neo Antisep } \\
\text { 3ml tiap } 5 \text { liter air minum, } \\
\text { Medisep 3ml tiap } 10 \text { liter air } \\
\text { minum. Ayam yang terserang } \\
\text { penyakit saluran pernapasan } \\
\text { segera diobati agar tidak } \\
\text { rentang terhadap serangan } \\
\text { E.Coli. Untuk Pengobatan } \\
\text { pemberian Obat Coliquin, } \\
\text { Doxytin, Koleridin, Tetra- } \\
\text { Chlor, Neo Medetril atau } \\
\text { Respiratrek (pilih salah satu } \\
\text { dan berikan sesuai aturan } \\
\text { pakai). dan Pemberian Vita } \\
\text { Stress 4-5 Hari setelah } \\
\text { pengobatan selesai agar } \\
\text { membantu penyembuhan } \\
\text { penyakit. }\end{array}$ \\
\hline & & & P8 & Hidrops Ascites & $\begin{array}{l}\text { Melakukan pengobatan } \\
\text { terhadap ayam yang terkena } \\
\text { gangguan pernapasan yang } \\
\text { disebabkan oleh bakteri } \\
\text { dengan pemberian Ampicol, } \\
\text { Doxitin, Doxyvet, Coliquin, } \\
\text { Neo Medetril atau Respiratrek } \\
\text { (Pilih salah satu dan berikan } \\
\text { sesuai aturan pakai). } \\
\text { melakukan pengecekan }\end{array}$ \\
\hline
\end{tabular}




\begin{tabular}{|c|c|c|}
\hline kd_penyakit & nama_penyakit & Solusi \\
\hline & & 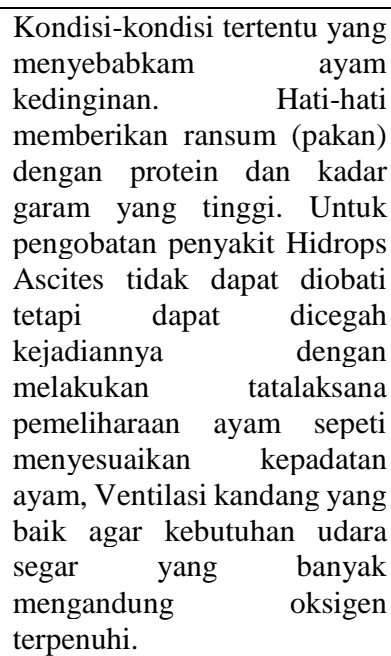 \\
\hline P9 & $\begin{array}{l}\text { Marek's } \\
\text { Disease }\end{array}$ & $\begin{array}{l}\text { Melakukan Vaksinasi Marek } \\
\text { pada ayam yang belum } \\
\text { tertular penyakit MD dan } \\
\text { Memisahkan ayam yang telah } \\
\text { terkena panyakit MD. } \\
\text { Melakukan sanitas pada } \\
\text { tempat ransum dan air minum } \\
\text { sampai benar-benar bersih. } \\
\text { Untuk pengobatan Tidak ada } \\
\text { obat yang dapat } \\
\text { menyembuhkan penyakit } \\
\text { MD. Ayam yang sakit tidak } \\
\text { produktif dan ekonomis untuk } \\
\text { dipelihara lebih lanjut. }\end{array}$ \\
\hline P10 & $\begin{array}{c}\text { Avian } \\
\text { Tubercullosis } \\
\text { (TBC Ayam) }\end{array}$ & $\begin{array}{l}\text { Melakukan Tes tuberculinasi } \\
\text { sedini mungkin, setelah } \\
\text { terjadi wabah TBC secara } \\
\text { pasti keluarkan seluruh ayam } \\
\text { dan lakukan sanitasi kandang } \\
\text { beserta peralatan kandang } \\
\text { lainnya. Ayam yang telah } \\
\text { terkena penyakit TBC } \\
\text { sebaiknya dimusnahkan } \\
\text { sebab berbahaya bagi } \\
\text { manusia.Apabila secara } \\
\text { keseluruhan ayam terkena } \\
\text { penyakit TBC sebaiknya } \\
\text { kandang dikosongkan } \\
\text { minimal } 1 \text { tahun. Untuk } \\
\text { pengobatan belum ada obat } \\
\text { yang efektif untuk } \\
\text { menyembuhkan penyakit } \\
\text { TBC Ayam. }\end{array}$ \\
\hline
\end{tabular}

Tabel 3.2. Data Gejala

\begin{tabular}{|c|l|}
\hline kd_gejala & \multicolumn{1}{c|}{ nama_gejala } \\
\hline G1 & $\begin{array}{l}\text { Kulit pada Kaki tampak berwarna merah } \\
\text { kebiruan. }\end{array}$ \\
\hline
\end{tabular}

\begin{tabular}{|c|c|}
\hline kd_gejala & nama_gejala \\
\hline G2 & $\begin{array}{l}\text { Jengger dan Pial tampak berwarna merah } \\
\text { kebiru-biruan. }\end{array}$ \\
\hline G3 & $\begin{array}{l}\text { Otot/daging ayam yang mati tampak } \\
\text { berwarna kebiruan. }\end{array}$ \\
\hline G4 & $\begin{array}{l}\text { keluar leleran lendir kental dari rongga } \\
\text { mulut dan hidung }\end{array}$ \\
\hline G5 & $\begin{array}{l}\text { Kloaka kotor dan terdapat fases (Kotoran } \\
\text { Ayam) menempel. }\end{array}$ \\
\hline G6 & Leher terpuntir dan gemetar. \\
\hline G7 & $\begin{array}{l}\text { Bulu Ayam tampak kusam, berdiri dan } \\
\text { ayam cenderung bergerombol. }\end{array}$ \\
\hline G8 & $\begin{array}{l}\text { Fases (kotoran ayam) berwarna hijau } \\
\text { disertai adanya gumpalan warna putih. }\end{array}$ \\
\hline G9 & Persendihan kaki bengkak dan panas. \\
\hline G10 & Ayam terdengar ngorok \\
\hline G11 & Ayam terdengar bersin \\
\hline G12 & Bagian muka tampak membengkak \\
\hline G13 & $\begin{array}{l}\text { Mata membengkak disertai adanya } \\
\text { timbunan eksudat/massa pada sinus bawah } \\
\text { mata berwarna kuning seperti keju. }\end{array}$ \\
\hline G14 & Nafsu makan berkurang \\
\hline G15 & Jengger membengkak dan keras. \\
\hline G16 & Daerah lubang hidung berwarna hitam \\
\hline G17 & $\begin{array}{l}\text { keluar leleran bening disertai bau busuk } \\
\text { (amis) pada hidung }\end{array}$ \\
\hline G18 & Seluruh anggota tubuh tampak gemetar. \\
\hline G19 & Angka kematian semakin tinggi \\
\hline G20 & $\begin{array}{l}\text { Fases (kotoran Ayam) encer/diare } \\
\text { berwarna putih }\end{array}$ \\
\hline G21 & $\begin{array}{l}\text { Ayam tampak sering mematuki bulu } \\
\text { disekitar anus. }\end{array}$ \\
\hline G22 & Fases (Kotoran ayam) bercampur darah \\
\hline G23 & Terjadi penurunan berat badan (kurus) \\
\hline G24 & Terjadi Peradangan pada Pusar \\
\hline G25 & $\begin{array}{l}\text { Tampak Perdarahan berupa garis pada otot } \\
\text { paha dan dada. }\end{array}$ \\
\hline G26 & $\begin{array}{l}\text { Perut tampak membesar (kembung) jika } \\
\text { diraba terasa adanya cairan di dalamnya. }\end{array}$ \\
\hline G27 & Bagian kepala tampak pucat \\
\hline G28 & $\begin{array}{l}\text { Salah satu sayap terkulai atau bahkan } \\
\text { keduanya. }\end{array}$ \\
\hline G29 & $\begin{array}{l}\text { terjadi kelumpuhan pada kaki dan salah } \\
\text { satu kaki terjulur kedepan. }\end{array}$ \\
\hline G30 & $\begin{array}{l}\text { Ayam mati secara tiba-tiba dengan kondisi } \\
\text { tubuh masih tampak sehat. }\end{array}$ \\
\hline G31 & $\begin{array}{l}\text { Jengger dan Pial tampak pucat dan } \\
\text { mengkerut. }\end{array}$ \\
\hline
\end{tabular}


JurnalIlmiahIlmuKomputer Vol. 5, No. 1, April 2019

Fakultas Ilmu Komputer

Universitas AL Asyariah Mandar

\begin{tabular}{|c|c|}
\hline kd_gejala & nama_gejala \\
\hline G32 & $\begin{array}{l}\text { Mati Mendadak, sebelum mati } \\
\text { mengibaskan sayap seperti mau terbang. }\end{array}$ \\
\hline
\end{tabular}

Tabel 3.3. Data Pengetahuan

\begin{tabular}{|c|c|c|c|c|}
\hline $\begin{array}{c}\text { Id } \\
\text { penyakit }\end{array}$ & $\begin{array}{c}\text { Kode } \\
\text { Penyakit }\end{array}$ & Id Gejala & $\begin{array}{l}\text { Kode } \\
\text { Gejala }\end{array}$ & Belief \\
\hline 1 & P1 & 1 & G1 & 0.7 \\
\hline 1 & P1 & 2 & G2 & 0.8 \\
\hline 1 & P1 & 3 & G3 & 0.9 \\
\hline 2 & P2 & 8 & G8 & 0.8 \\
\hline 2 & P2 & 9 & G9 & 0.7 \\
\hline 2 & P2 & 10 & G10 & 0.9 \\
\hline 2 & P2 & 11 & G11 & 0.6 \\
\hline 2 & $\mathrm{P} 2$ & 12 & G12 & 0.7 \\
\hline 3 & P3 & 15 & G15 & 0.6 \\
\hline 3 & P3 & 16 & G16 & 0.8 \\
\hline 3 & P3 & 17 & G17 & 0.9 \\
\hline 4 & P4 & 4 & G4 & 0.9 \\
\hline 4 & P4 & 19 & G19 & 0.5 \\
\hline 4 & P4 & 18 & G8 & 0.7 \\
\hline 5 & P5 & 5 & G5 & 0.4 \\
\hline 5 & P5 & 20 & G20 & 0.5 \\
\hline 5 & P5 & 21 & $\mathrm{G} 21$ & 0.8 \\
\hline 5 & P5 & 25 & G25 & 0.9 \\
\hline 5 & P5 & 7 & G7 & 0.4 \\
\hline 6 & P6 & 22 & G22 & 0.9 \\
\hline 6 & P6 & 23 & $\mathrm{G} 23$ & 0.7 \\
\hline 6 & P6 & 14 & G14 & 0.6 \\
\hline 7 & P7 & 13 & G13 & 0.7 \\
\hline 7 & P7 & 24 & $\mathrm{G} 24$ & 0.9 \\
\hline 8 & P8 & 26 & G26 & 0.9 \\
\hline 8 & P8 & 27 & G27 & 0.8 \\
\hline 9 & P9 & 28 & $\mathrm{G} 28$ & 0.9 \\
\hline
\end{tabular}

Copyright () 2020 FIKOM - UNASMAN

http://ejournal.fikom-unasman.ac.id
(P) ISSN 2442-451X

(O) ISSN 2503-3832

\begin{tabular}{|c|c|c|c|c|}
\hline $\begin{array}{c}\text { Id } \\
\text { penyakit }\end{array}$ & $\begin{array}{c}\text { Kode } \\
\text { Penyakit }\end{array}$ & Id Gejala & $\begin{array}{c}\text { Kode } \\
\text { Gejala }\end{array}$ & Belief \\
\hline 9 & P9 & 29 & G29 & 0.8 \\
\hline 9 & P9 & 6 & G6 & 0.4 \\
\hline 10 & P10 & 31 & G31 & 0.9 \\
\hline 10 & P10 & 30 & G30 & 0.6 \\
\hline 8 & P8 & 32 & G32 & 0.5 \\
\hline
\end{tabular}

\subsection{Kerangka Sistem}

Kerangka system pada penelitian ini sebagai berikut:.

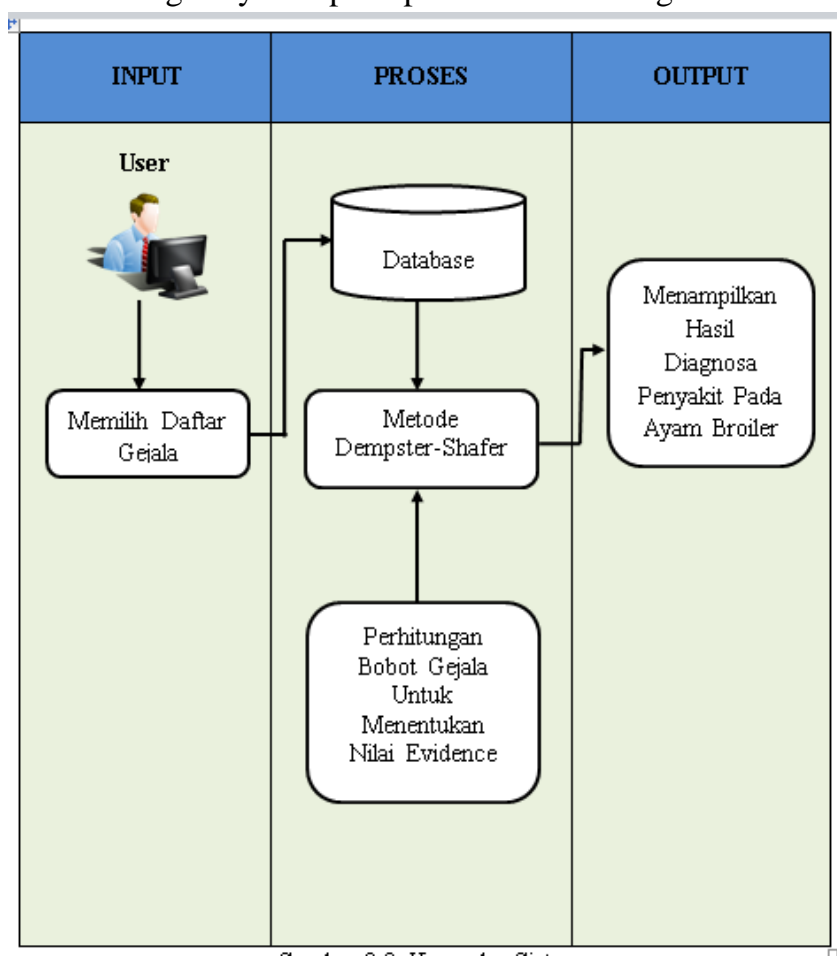

Gambar 3.2. KerangkaSistem

Gambar 3.2. merupakan kerangka system yang menggambarkan model dari system yang dibangun. Ketika user memili daftar gejala pada system maka data base akan menampung kemudian dilakukan peritungan dengan metode Demster Safer untuk mengetaui nilai evidence berdasarkan bobot gejala. Hasil akan memberikan nilai diagnosa berupa persentase kecenderungan. Informasi lainnya berupa persentasi penyakit, nama penyakit yang di derita dan cara penanganan.

\section{HASIL PENELITIAN}

\subsection{Perhitungan Dempster-Shafer}

Adapun contohperhitungandenganmenggunakanmetode Dempster-Shafersebagaiberikut : 
JurnalIlmiahIlmuKomputer Vol. 5, No. 1, April 2019

Fakultas Ilmu Komputer

Universitas AL Asyariah Mandar

Gejala yang dipilih:

a. G9 | Persendihan kaki bengkak dan panas = P2

b. G8 | Fases (kotoran ayam) berwarna hijau disertai adanya gumpalan warna putih $=\mathrm{P} 2$

c. G1 | Kulit pada Kaki tampak berwarna merah kebiruan. = P1

Berikut Proses Perhitungannya :

1. Menentukan nilai Plausibility
a. $\mathrm{G} 9=1-0.7=0.3$
b. $\mathrm{G} 8=1-0.8=0.2$
c. $\mathrm{G} 1=1-0.7=0.3$

2. Perihitungan

a. $\mathrm{G} 9=\mathrm{P} 2$ dan $\mathrm{G} 8=\mathrm{P} 2$

Dimana :

$\mathrm{X} 1=0.8$ dan $\mathrm{X} \varnothing=0.2$

$\mathrm{Y} 1=0.7$ dan $\mathrm{Y} \emptyset=0.3$

Proses perhitungan awal

$\mathrm{X} 1 * \mathrm{Y} 1=0.8 * 0.7=0.56=\mathrm{P} 2$

$\mathrm{X} 1 * \mathrm{Y} \varnothing=0.8 * 0.3=0.24=\mathrm{P} 2$

$\mathrm{X} \varnothing * \mathrm{Y} 1=0.2 * 0.7=0.14=\mathrm{P} 2$

$\mathrm{X} \emptyset * \mathrm{Y} \emptyset=0.2 * 0.3=0.6=\varnothing$

Merujuk nilai irisan $(\mathrm{K})$ belum ada maka nilai $\mathrm{K}=0$

$\mathrm{M}(\mathrm{z})=(0.56+0.24+0.14) /(1-(\mathrm{K}=0))$

$\mathrm{M}(\mathrm{P} 2)=0.94$

Menentukan niilaiplausability $\mathrm{M}(\mathrm{P} 2)$

$\mathrm{M}(\mathrm{P} 2)=1-0.94=0.06$

a. $\mathrm{G} 1=\mathrm{P} 1$ dan $\mathrm{M}(\mathrm{z})=\mathrm{P} 2$

Dimana :

$\mathrm{X} 1=0.94$ dan $\mathrm{X} \varnothing=0.06$

$\mathrm{Y} 1=0.7$ dan $\mathrm{X} \varnothing=0.3$

Proses perhitungan kedua

$\mathrm{X} 1 * \mathrm{Y} 1=0.94 * 0.7=0.658=\varnothing$

$\mathrm{X} 1 * \mathrm{Y} \emptyset=0.94 * 0.3=0.282=\mathrm{P} 2$

$\mathrm{X} \emptyset * \mathrm{Y} 1=0.06 * 0.7=0.042=\mathrm{P} 1$

$\mathrm{X} \varnothing * \mathrm{Y} \emptyset=0.06 * 0.3=0.018=\varnothing$

Merujuk nilai irisan $(\mathrm{K})$ ada maka nilai $\mathrm{K}=0,658$ dimana nilai $\mathrm{K}$ didapat dari perhitungan awal $\mathrm{X} 1 * \mathrm{Y} 1=$ $0.94 * 0.7=0.658$.

Maka :

$\mathrm{M}(\mathrm{z})=(0.282 /(1-(\mathrm{K}=0.658))$

$\mathrm{Mz}(\mathrm{P} 2)=0.82456140350877$

$\mathrm{M}(\mathrm{z})=(0.042 /(1-(\mathrm{K}=0.658))$

$\mathrm{Mz}(\mathrm{P} 1)=0.12280701754386$

Penyakit Terbesar P2= ChronicRespiratoryDisearce (CRD) dengan nilai keyakinan $\mathbf{8 2 . 4 6 \%}$

\subsection{User Interface Sistem Pakar}

a. Halaman Data Penyakit

Gambar 3.3 merupakan data penyakit yang tela dikumpulkan sebagai basis pengetauan dilengkapi dengan kode penyakit yang akan memudakan system dalam mengenali setiap penyakit kemudian mengubungkan pada setiap gejala yang ada pada table gejala.
(P) ISSN 2442-451X

(O) ISSN 2503-3832
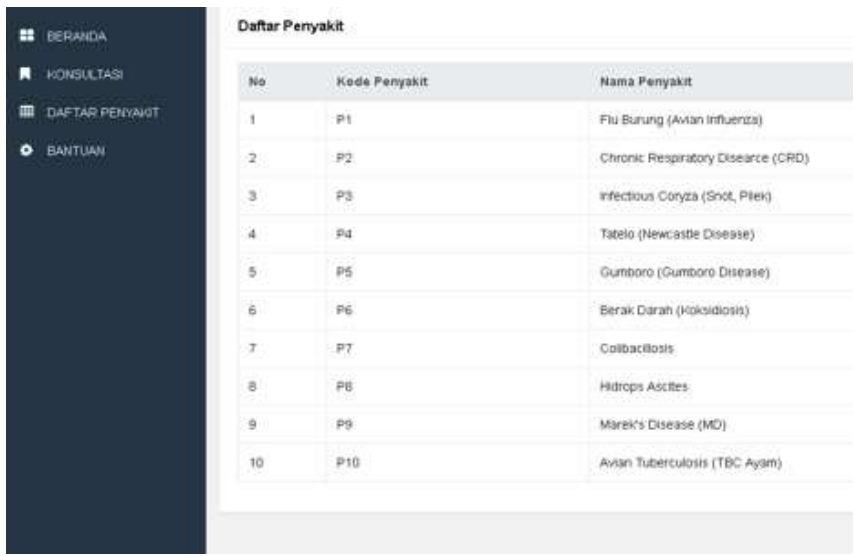

Gambar 3.3 Halaman Data Penyakit

b. Halaman Data Gejala

Gambar 3.4 merupakan gejala atau ciri-ciri dari setiap penyakit. Data ini akan dicocokkan dengan tabel penyakit untuk menentukan asil diagnosa.
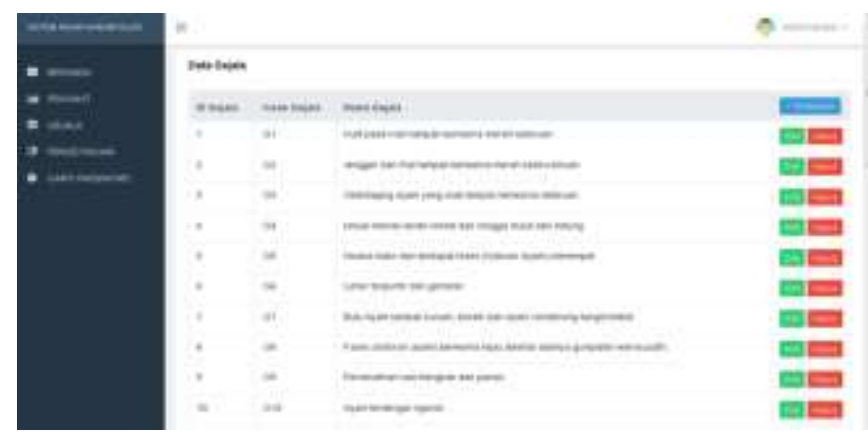

Gambar 3.4 Halaman Data Gejala

c. Halaman Basis Pengetahuan

Gambar 3.5 merupakan basis pengetauan yang dibangun dari table gejala dan table penyakit. Tabel inila yang akan dikenali ole mesi inferensi dan mengasilkan diagnose.
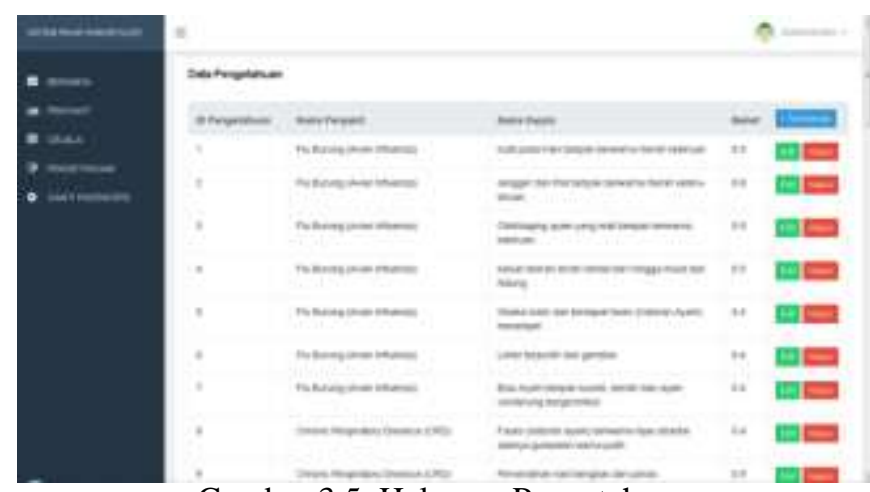

Gambar 3.5. Halaman Pengetahuan

\section{d. Halaman Konsultasi}

Selain basis pengetauan system ini juga dilengkapi dengan alaman konsultasi untuk menemukan solusi dari setiap asil 
JurnalIlmiahIlmuKomputer Vol. 5, No. 1, April 2019

Fakultas Ilmu Komputer

Universitas AL Asyariah Mandar

diagnosi. Alaman konsultasi berupa system Freetly Asked uestion (FA)
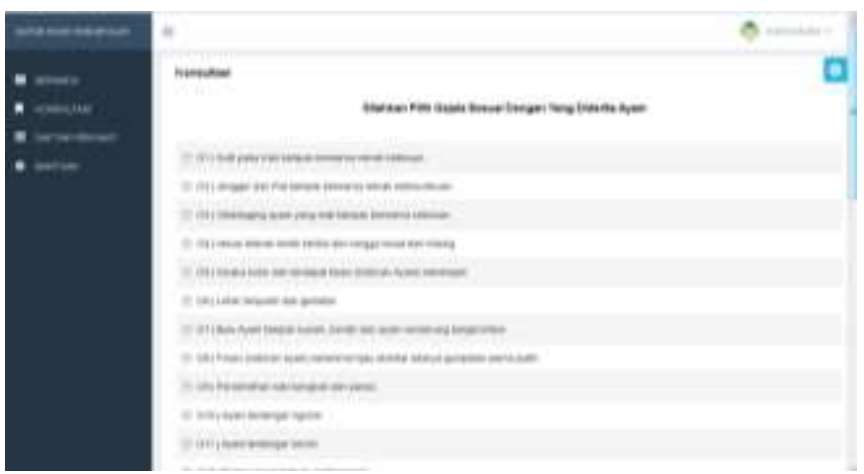

Gambar 3.6. Halaman Kosultasi

\section{e. Halaman Hasil Diagnosa}

Halaman hasil diagnosa pada system disajikan pada gambar 3.7. Informasi tersebut tela sesuai dengan asil peritungan manual. Dari data simulasi ditemukan asil diagnose penyakit terbesar $\mathbf{P 2}=$ Chronic Respiratory Disearce (CRD) dengan nilai keyakinan $\mathbf{8 2 . 4 6 \%}$
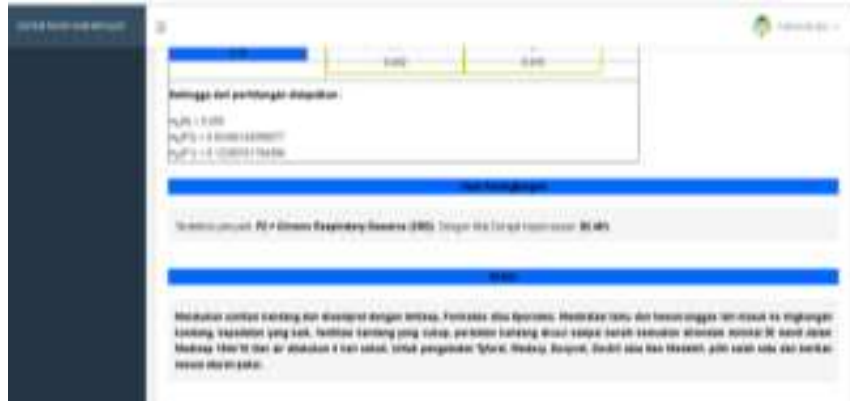

Gambar 3.7. Halaman Hasil Diagnosa

\subsection{Pengujian Black Box}

Pengujian fitur pada sistem menggunakan black box adapun hasil pengujian disajikan pada tabel 4.1.

Tabel 4.1. Pengujian Black Box

\begin{tabular}{|c|c|c|}
\hline $\begin{array}{c}\text { Fitur Yang } \\
\text { Diujikan }\end{array}$ & Hasil Yang Diharapkan & Kesimpulan \\
\hline Login & $\begin{array}{c}\text { Sistem mampu menerima } \\
\text { imputan login }\end{array}$ & Sesuai \\
\hline $\begin{array}{c}\text { Input Data } \\
\text { Fakta Gejala }\end{array}$ & $\begin{array}{c}\text { Sistem mampu menerima } \\
\text { input data gejala untuk } \\
\text { proses diagnosa }\end{array}$ & Sesuai \\
\hline $\begin{array}{c}\text { Sistem mampu } \\
\text { menampilkan hasil } \\
\text { diagnosa berdasarkan } \\
\text { gejala yang dimasukkan } \\
\text { pengguna }\end{array}$ & Sesuai \\
\hline $\begin{array}{c}\text { Form Data } \\
\text { Penyakit }\end{array}$ & $\begin{array}{c}\text { Muncul form untuk } \\
\text { menambahkan data } \\
\text { penyakit baru }\end{array}$ & Sesuai \\
\hline
\end{tabular}

Copyright @ 2020 FIKOM - UNASMAN

http://ejournal.fikom-unasman.ac.id
(P) ISSN 2442-451X

(O) ISSN 2503-3832

\begin{tabular}{|c|c|c|}
\hline $\begin{array}{c}\text { Fitur Yang } \\
\text { Diujikan }\end{array}$ & Hasil Yang Diharapkan & Kesimpulan \\
\hline $\begin{array}{l}\text { Simpan Data } \\
\text { Penyakit }\end{array}$ & $\begin{array}{c}\text { Data baru tersimpan dalam } \\
\text { tabel penyakit }\end{array}$ & Sesuai \\
\hline $\begin{array}{c}\text { Edit Data } \\
\text { Penyakit }\end{array}$ & $\begin{array}{c}\text { Muncul form untuk } \\
\text { mengedit data penyakit }\end{array}$ & Sesuai \\
\hline $\begin{array}{c}\text { Menyimpan } \\
\text { Perubahan } \\
\text { Data Yang } \\
\text { Telah } \\
\text { Dilakukan }\end{array}$ & $\begin{array}{l}\text { Data yang di edit berhasil } \\
\text { terubah dan tersimpan }\end{array}$ & Sesuai \\
\hline $\begin{array}{l}\text { Delete Data } \\
\text { Penyakit }\end{array}$ & $\begin{array}{l}\text { Ketika tombol delete di } \\
\text { klik maka sistem akan } \\
\text { menghapus data penyakit }\end{array}$ & Sesuai \\
\hline $\begin{array}{l}\text { Form Data } \\
\text { Gejala }\end{array}$ & $\begin{array}{c}\text { Muncul form untuk } \\
\text { menambahkan data gejala } \\
\text { baru }\end{array}$ & Sesuai \\
\hline $\begin{array}{c}\text { Simpan Data } \\
\text { Gejala }\end{array}$ & $\begin{array}{c}\text { Data baru tersimpan dala } \\
\text { tabel tebel gejala }\end{array}$ & Sesuai \\
\hline $\begin{array}{l}\text { Edit Data } \\
\text { Gejala }\end{array}$ & $\begin{array}{l}\text { Muncul form untuk } \\
\text { mengedit data gejala }\end{array}$ & Sesuai \\
\hline $\begin{array}{l}\text { Hapus Data } \\
\text { Gejala }\end{array}$ & $\begin{array}{l}\text { Ketika tombol hapus di } \\
\text { klik maka sistem akan } \\
\text { menghapus data gejala }\end{array}$ & Sesuai \\
\hline $\begin{array}{c}\text { Form Data } \\
\text { Pengetahuan }\end{array}$ & $\begin{array}{l}\text { Muncul form untuk } \\
\text { menampilakan data } \\
\text { pengetahuan baru }\end{array}$ & Sesuai \\
\hline $\begin{array}{l}\text { Simpan Data } \\
\text { Pengetahuan }\end{array}$ & $\begin{array}{l}\text { Data baru tersimpan dalam } \\
\text { tabel pengetahuan }\end{array}$ & Sesuai \\
\hline $\begin{array}{c}\text { Edit Data } \\
\text { Pengetahuan }\end{array}$ & $\begin{array}{l}\text { Muncul form untuk } \\
\text { mengedit data } \\
\text { pengetahuan }\end{array}$ & Sesuai \\
\hline $\begin{array}{l}\text { Menyimpan } \\
\text { Data } \\
\text { Perubahan } \\
\text { Pengetahuan }\end{array}$ & $\begin{array}{c}\text { Data yang di edit berhasil } \\
\text { terubah dan tersimpan } \\
\text { kembali dalam tabel } \\
\text { pengetahuan }\end{array}$ & Sesuai \\
\hline $\begin{array}{l}\text { Hapus Data } \\
\text { Pengetahuan }\end{array}$ & $\begin{array}{l}\text { Ketika tombol hapus di } \\
\text { klik maka sistem akan } \\
\text { menghapus data } \\
\text { pengetahuan }\end{array}$ & Sesuai \\
\hline $\begin{array}{c}\text { Hasil } \\
\text { Diagnosa }\end{array}$ & $\begin{array}{c}\text { Hasil diagnosa sistem } \\
\text { sesuai dengan perhitungan } \\
\text { manual sebelumnya }\end{array}$ & Sesuai \\
\hline
\end{tabular}


JurnalllmiahIlmuKomputer Vol. 5, No. 1, April 2019

Fakultas Ilmu Komputer

Universitas AL Asyariah Mandar

\section{KESIMPULAN}

system pakar untuk mendiagnosa penyakit pada ayam broiler tela mengumpulkan sebanyak 10 jenis penyakit berdasarkan gejala yang dimasukkan. Sebagai perhitungan nilai probabilitasnya menggunakan metode Dempster Shafer yang mengkombinasikan penyakit yang diderita berupa nama, defenisi penyebab, solusi yang dilengkapi dengan nilai presentase dari penyakit tersebut yang dapat digunakan seperti seorang pakar dala mmendiagnosa penyakit. Pengujian 15 ekor aya tela memberikan nilai persentase terbaik dan akurasi yang tinggi.

\section{UCAPAN TERIMA KASIH}

Terima kasi kepada pengelola laboratorium riset Fakultas Ilmu komputer dan tim peneliti yang membantu dalam proses penelitian, serta juga kepada peternak ayam broiler yang telah memberikan informasi dan data penelitian.

\section{Daftar Pustaka}

[1] Bambang Yuwono, 2011, Sistem Pakar Diagnosa Penyakit Ayam Menggunakan Perintah Suara. TELEMATIKA, 7(2), 77-86.

[2] Santo, Ali Mulyanto, 2017, Penerapan Metode DemsterShafer Pada Sistem Pakar Diagnosa Penyakit Ayam Broiler Menggunakan VB.Net 2008 Di Prima AdistwaFarm Cilacap. Jurnal InformatikaSIMANTIK, 2(2).

[3] Siti Rohajawati, Rina Supriyati, 2010, Sistem Pakar Diagnosis Penyakit Unggas Dengan Metode CertaintyFactor.CommIT, 4(1), 41-46

[4] Siti Rohajawati, Rina Supriyati, 2010, Sistem Pakar Diagnosis Penyakit Unggas Dengan Metode CertaintyFactor.CommIT, 4(1), 41-46.

[5] Garuda Ginting, SiskaSubuhHatiTaringan, Fadlina, 2017, SistemPakarMendiagnosaPenyakitGumboro Pada Ayam Broiler DenganMetode Certainty Factor. Media Informatika Budi Darma, 1(2), 54-57.

[6] Mohammad Hadi, M. Misdram, Ratih Fitri Aini, 2016, Perancangan Sistem Pakar Diagnosa Penyakit Ayam Dengan Metode ForwardChaining. JIMP - Jurnal Informatika Merdeka Pasuruan, 2(1).

[7] Soni Darsono, 2017, Diagnosa Penyakit Kulit Pada Sapi Menggunakan Metode Dempster-Shafer. SimkiTechsain.

[8] Mikha Dayan Sinaga, Nita Sari Br. Sembiring, 2016, Penerapan Metode Dempster Shafer Untuk Mendiagnosa Penyakit Dari Akibat Bakteri Salmonella. Cogito Smart Journal.
(P) ISSN 2442-451X

(O) ISSN 2503-3832

[9] Andry Sadjaja, Andi Wahyu Rahardjo Emanuel, Maresha Caroline Wijanto, 2016, Sistem Pakar Deteksi Penyakit Ayam Dengan Media Interaktif. SENTIKA, Yogyakarta.

[10] Asep Afandi, 2018, Sistem Pakar Identifikasi Penyakit Ayam Pedaging. Jurnal Cendekia, Bandarlampung.

[11] Amanda Patria Putra, Cahya Rahmad, 2015, Analisa Perbandingan Metode CertaintyFactor Dan DempsterShafer Pada Sistem Pakar Diagnosa Penyakit Diabetes Melitus. Jurnal Informatika Polinema.

[12] Arjon Samuel Sitio, 2018, Sistem Pakar Untuk Mendiagnosa Penyakit Jantung Menggunakan Metode DempsterShafer. JournalOfInformatic Pelita Nusantara, 3(1).

[13] Mikha Dayan Sinaga, Nita Sari Br. Sembiring, 2016, PenerapanMetode Dempster Shafer UntukMendiagnosaPenyakit Dari AkibatBakteri Salmonella. Cogito Smart Journal.

[14] Wasir Ibrahim, Rita Mutia, Nurhayati, Nelwida, dan Berliana, 2016, Penggunaan Kulit Nanas Fermentasi Dalam Ransum Yang Mengandung Gulma Berkhasiat Obat Terhadap Konsumsi Nutrient Ayam Broiler. AGRIPET.

[15] Widya Paramita Lokapirnasari, Andreas Berny Yulianto, 2014, Gambaran Sel Eosinofil, Monosit, dan Basofil Setelah Pemberian Spirulina Pada Ayam yang Diinfeksi Virus Flu Burung. Jurnal Veteriner, 15(4), 499-505. 